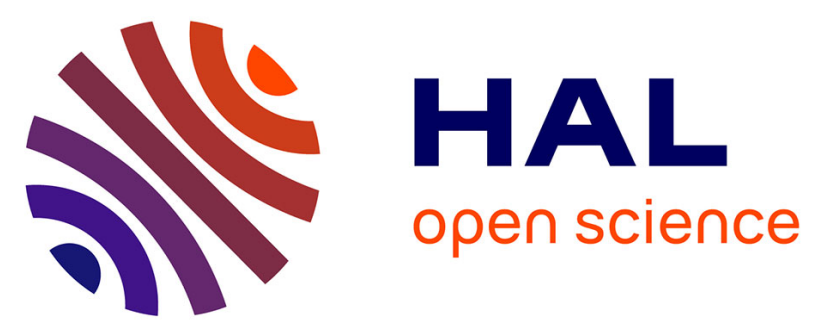

\title{
Ex situ evaluation of the composition of protein corona of intravenously injected superparamagnetic nanoparticles in rats
}

Usawadee Sakulkhu, Lionel Maurizi, Morteza Mahmoudi, Mahdi Motazacker, Marcel Vries, Azza Gramoun, Marie-Gabrielle Ollivier Beuzelin, Jean-Paul Vallée, Farhad Rezaee, Heinrich Hofmann

\section{To cite this version:}

Usawadee Sakulkhu, Lionel Maurizi, Morteza Mahmoudi, Mahdi Motazacker, Marcel Vries, et al.. Ex situ evaluation of the composition of protein corona of intravenously injected superparamagnetic nanoparticles in rats. Nanoscale, 2014, 6 (19), pp.11439-11450. 10.1039/C4NR02793K . hal02163344

\section{HAL Id: hal-02163344 \\ https://hal.science/hal-02163344}

Submitted on 9 Mar 2021

HAL is a multi-disciplinary open access archive for the deposit and dissemination of scientific research documents, whether they are published or not. The documents may come from teaching and research institutions in France or abroad, or from public or private research centers.
L'archive ouverte pluridisciplinaire HAL, est destinée au dépôt et à la diffusion de documents scientifiques de niveau recherche, publiés ou non, émanant des établissements d'enseignement et de recherche français ou étrangers, des laboratoires publics ou privés. 


\section{PAPER}

\section{Ex situ evaluation of the composition of protein corona of intravenously injected superparamagnetic nanoparticles in rats}

Cite this: DOI: 10.1039/xoxxooooox

Received ooth January 2012, Accepted ooth January 2012

DOI: $10.1039 / \times 0 x x 00000 x$

www.rsc.org/

\author{
Usawadee Sakulkhu ${ }^{\mathrm{a}}$, Lionel Maurizi ${ }^{\mathrm{a}}$, Morteza Mahmoudi*bc, Mahdi \\ Motazacker ${ }^{\mathrm{d}}$, Marcel Vries ${ }^{\mathrm{e}}$, Azza Gramoun ${ }^{\mathrm{f}}$, Marie-Gabrielle Ollivier Beuzelin ${ }^{\mathrm{a}}$, \\ Jean-Paul Vallée ${ }^{f}$, Farhad Rezaee*ef, Heinrich Hofmann*a
}

\section{Introduction}

Superparamagnetic iron oxide nanoparticles (SPIONs) are promising advanced materials for various biomedical applications, such as targeted drug delivery, contrast agent for imaging, cell tracking, and transfections. ${ }^{1-6}$ Iron oxide, $\gamma-\mathrm{Fe}_{2} \mathrm{O}_{3}$, is of special interest because of the approved biocompatibility of these nanoparticles (NPs), including the well understood metabolism of the NPs in the liver. ${ }^{7}$ For most biomedical applications, the NPs are in contact with or taken up by various cell types; in this case, the physicochemical properties of the NPs, and of their surface in particular, play a crucial role in their interaction with cells.

Studies conducted in the past few decades on the interaction of engineered nanomaterials with biologically relevant molecules have improved our understanding of the behavior of these materials in human and animal bodies and have helped to identify in vitro assays that are predictive of in vivo biodistribution or toxicities. However, there are still valid concerns regarding in vitro methods for determining the biocompatibility of NPs or toxicity tests for engineered NPs. ${ }^{8}$ After NPs have been in contact with biological media, their surfaces are covered by various biomolecules (e.g., proteins), forming what is known as a "protein corona".9-14 One reason for concern is the still unpredictable composition of the protein corona in vivo. ${ }^{15}$

In protein mixtures, the adsorption behavior is the result of competitive transport, adsorption, desorption, and repulsion processes. Small proteins diffuse faster than large ones and, therefore, are detected at higher concentrations compared to the bulk concentration in the early adsorption stage. However, larger proteins have a greater potential to cover the surface because of a larger contact area, which can lead to desorption of the pre-adsorbed proteins during spreading on the surface. Either a monolayer or multilayers are formed depending on the $\mathrm{pH}$, ionic strengths, temperature, and protein-protein interaction. ${ }^{16}$ A continuous adsorption-desorption process has been observed for a contact time of $100 \mathrm{~s}$ and a layer thickness of several nanometers on the surface of NPs. ${ }^{17}$ Thus, the cell actually "sees" the corona-coated NPs, rather than pristine NPs. ${ }^{14}$

The effects of different physicochemical properties of NPs (e.g., composition, size, shape, crystallinity, surface area, surface defects, charge, roughness, transfer capability, and hydrophobicity/hydrophilicity) and environmental factors (e.g. [induced] temperature and gradient plasma concentration) on the formation of the corona have been investigated in detail. ${ }^{13}$, ${ }^{18}$ Because separation of NPs from the in vivo environment was 
not possible using available techniques, all the corona evaluations at the surface of NPs were performed in vitro. However, very recent reports confirmed that the in vitro protein corona information does not accurately predict hematocompatibility of colloidal NPs; thus, in vivo evaluation of the protein corona is required to accurately predict the fate of NPs inside the human body.

Here, using the unique magnetic properties of SPIONs, NPs were extracted from rat sera after interacting with the rat's physiological system in vivo. We believe that the composition of the "hard protein corona" (the tightly adsorbed proteins at the NPs' surface) corresponds much better to the composition in vivo than the composition detected after the particles have been incubated in serum in vitro. In this paper, we not only show the difference between the composition of the hard corona detected after incubation in blood in vivo and the corresponding serum in vitro, we also present an interesting method to use core shell nanoparticles to investigate the influence of coatings and surface properties of particles which cannot be separated magnetically.

\section{Experimental}

\section{Preparation of the various SPIONs}

The SPIONs were prepared via alkaline co-precipitation, and polyvinyl alcohol (PVA) coatings were prepared as described previously. ${ }^{19,} 20$ The PVA, which had an average molecular weight of $14,000 \mathrm{~g} / \mathrm{mol}$ and a hydrolysis degree of $85 \%$ (Mowiol@ 3-85), and the carboxylic functionalized polyvinyl alcohol copolymer (KL-506), which had an average molecular weight of 30,000-50,000 g/mol and a hydrolysis degree of 74$80 \%$, were supplied by Kuraray Specialties Europe $\mathrm{GmbH}$, Hattersheim am Main, Germany. The vinylalcohol-vinylamine copolymer (M12), which had an average molecular weight of 80,000-140,000, was supplied by Erkol S.A, Tarragona, Spain. The polymers were dissolved in water then rapidly heated for 15 min (Mowiol® 3-85 and KL-506) or $4 \mathrm{~h} \mathrm{(M12)} \mathrm{at} 90^{\circ} \mathrm{C}$. Ultrapure deionized water (Seralpur delta UV/UF setting, 0.055 $\mu \mathrm{S} / \mathrm{cm}$ ) was used in all synthesis steps.

Positively charged, neutral, and negatively charged NPs were obtained by added a mixture of Mowiol®3-85 and M12 at a mass ratio of 45 (with a final concentration of $9 \%$ [w/v]), $9 \%$ (w/v) Mowiol®3-85, and 6\% (w/v) KL-506 solutions, respectively, to a $10 \mathrm{mg} \mathrm{Fe} / \mathrm{mL}$ SPION suspension at a volume ratio of $1: 1$. The mixture was preserved for at least 1 week and stored at $4{ }^{\circ} \mathrm{C}$ until used. The particle suspension was adjusted to $\mathrm{pH} 7.4$ for animal treatment.

\section{Particle characterization}

The hydrodynamic diameters of PVA-coated NPs after adjustment to $\mathrm{pH} 7.4$ were measured by dynamic laser scattering using a ZetaPALS equipped with a BI-9000AT digital autocorrelator (Brookhaven Instruments Cooperation, LABORCHEMIE GmbH, Austria). NPs were diluted in deionized water at $100 \mu \mathrm{g} \mathrm{Fe} / \mathrm{mL}$ and sonicated for a few seconds. The theoretical refractive index of 2.42 of magnetite ${ }^{21}$ was used to calculate the number-weighted distribution from the raw intensity-weighted data. The Smoluchowski method was chosen for data processing. Viscosity, refractive index, and dielectric constant of pure water were used to characterize the solvent. The zeta potential was also determined using the same instrument.

\section{Cytotoxicity study}

RAW 264.7 (mouse leukemic monocyte macrophage cell line) cells were maintained in Dulbecco's Modified Eagle Medium (DMEM, Gibco B-RL, Invitrogen AG, Basel, Switzerland) supplemented with $10 \%$ fetal bovine serum and $1 \%$ penicillin G/streptomycin sulfate $\left(10,000\right.$ units $\mathrm{mL}^{-1} ; 10,000 \mu \mathrm{g} \mathrm{mL} \mathrm{mL}^{-1}$; Gibco B-RL, Invitrogen AG, Basel, Switzerland) at $37^{\circ} \mathrm{C}$ under $5 \% \quad \mathrm{CO}_{2}$. One day before the experiments, the cells were scraped and seeded at a density of $85 \times 10^{3}$ cells per well (100 $\mu \mathrm{L}$ ) in flat-bottomed 96-well plates (Costar, Corning Incorporated, Maryland, USA). On the day of the experiments, the medium was changed to fresh complete medium with PVASPIONs at concentrations of $0.1,0.2,0.4$, and $0.8 \mathrm{mg} \mathrm{Fe} / \mathrm{mL}$. The cells were incubated at $37^{\circ} \mathrm{C}$ for $24 \mathrm{~h}$ and washed once with $120 \mu \mathrm{L}$ phosphate buffered saline (PBS).

For the live cell PrestoBlue cell viability assay, $100 \mu \mathrm{L}$ of $1 \times$ PrestoBlue reagent (Invitrogen, Switzerland) in complete medium was added per well, then further incubated at $37^{\circ} \mathrm{C}$ for $1 \mathrm{~h}$. The fluorescence was read at excitation and emission wavelengths of 535 and $615 \mathrm{~nm}$, respectively, using a microplate reader (Infinite 200 PRO, Tecan Group Ltd., Männedorf, Switzerland).

Data are presented as mean \pm standard deviation (SD). All analyses were performed three times $(n=3)$. Values were considered significant at $P<0.05$.

\section{Animal treatment}

All the experimental procedures were approval by the local animal care committees and were conducted in accordance with the guidelines of the Swiss Committee on Animal Experiments. Two-month-old female Lewis rats (approximately $200 \mathrm{~g}$, purchased from Javier France) were anesthetized with 5\% isoflurane. The rats were divided into four groups according to the injected liquids: $150 \mathrm{mM} \mathrm{NaCl}$ (control rat), positively charged NPs, neutral NPs, and negatively charged NPs. Then, NPs at $7 \mathrm{mg} \mathrm{Fe}$, corresponding to $10.36 \mathrm{mg}$ SPIONs, were injected intravenously through the tail. The rats were anesthetized with $5 \%$ isoflurane and killed $15 \mathrm{~min}$ after the injection. Various organs and blood were collected. The organs were weighed and stored at $-80^{\circ} \mathrm{C}$ until analysis. The blood was collected, allowed to clot at room temperature for $15 \mathrm{~min}$, and then centrifuged at $1,500 \mathrm{~g}$ for $15 \mathrm{~min}$ at $4^{\circ} \mathrm{C}$ (Labofuge 400R, Heraeus, Hanau, Germany) to separate the sera and blood cell compartments. The sera were loaded in a magnetic separator for protein separation.

\section{In vitro hard corona}

The blood volume of a $200 \mathrm{~g}$ rat was calculated based on the body weight using the experimentally determined equation of 
Lee and Blaufox ${ }^{22}: \mathrm{BV}=0.06 \times \mathrm{BW}+0.77$. Here, $\mathrm{BV}$ represents the blood volume in milliliters, and $\mathrm{BW}$ represents the body weight in grams. From the in vivo study, the serum volume was half the total blood volume after coagulation and blood cell separation. The SPIONs were incubated for $15 \mathrm{~min}$ at $37^{\circ} \mathrm{C}$ with rat serum (Ref. no. $10710 \mathrm{C}$, lot. 1229686A, Invitrogen Corporation, Frederick, Maryland, USA) and the same SPION/serum ratio as that in the in vivo study. After 15 min incubation, the hard corona proteins were separated using a magnetic separator, as described below.

\section{Ex vivo protein separation using a magnetic separator}

The hard corona-SPION complexes with excess serum proteins from the in vivo and in vitro experiments were loaded into a column in a magnetic reactor (Fig. S1). The trapped NPs (protein corona-NP complex) were then washed with solutions of increasing ionic strength: $1 \times$ PBS (Life Technologies Europe B.V., Switzerland) and $1 \times$ PBS with $\mathrm{NaCl}$ added to reach final concentrations of $0.5,1.0$, and $2.0 \mathrm{M}$. After being washed with the highest salt concentration solution, the trapped NPs were eluted from a Ni-Fe wire by removal of the magnets. The hard protein coronas were analyzed by liquid chromatography mass spectrometry/mass spectrometry (LC-MS/MS).

\section{Protein detection (LTQ-Orbitrap-XL)}

NPs were spun down by centrifugation at 20,000 g for $10 \mathrm{~min}$ and the pellet was resuspended in $25 \mu \mathrm{L}$ Sequencing Grade Trypsin $(12.5 \mathrm{ng} / \mu \mathrm{L}$ in $25 \mathrm{mM}$ ammonium bicarbonate) and digested using a CEM Discover Microwave Digestor for 15 min at $55^{\circ} \mathrm{C}(70 \mathrm{~W})$. The digestion was stopped by addition of $200 \mu \mathrm{L} \mathrm{50 \%}$ acetonitrile $+5 \%$ formic acid. The NPs were dried using a Thermo SpeedVac and resuspended in $13 \mu \mathrm{L} 5 \%$ acetonitrile containing $0.1 \%$ formic acid.

Samples were analyzed by NanoLC-MS/MS on an Ultimate 3000 system (Dionex, Amsterdam, The Netherlands) interfaced on-line with a LTQ-Orbitrap-XL mass spectrometer (ThermoFisher Scientific, San Jose, CA). Re-dissolved peptides were loaded onto a $5 \mathrm{~mm} \times 300 \mu \mathrm{m}$ i.d. trapping micro column packed with C18 PepMAP100 $5 \mu \mathrm{m}$ particles (Dionex) in $0.1 \%$ FA at a flow rate of $20 \mu \mathrm{L} / \mathrm{min}$. Upon loading and washing, peptides were back-flush eluted onto a $15 \mathrm{~cm} \times 75 \mu \mathrm{m}$ i.d. nano-column, packed with C18 PepMAP100 $3 \mu \mathrm{m}$ particles (Dionex). The mobile phase gradient was delivered at the flow rate of $300 \mathrm{~nL} / \mathrm{min}$ as follows: $5-50 \%$ solvent $\mathrm{B}$ in $93 \mathrm{~min}$; 50$80 \% \mathrm{~B}$ in $5 \mathrm{~min} ; 80 \% \mathrm{~B}$ for $10 \mathrm{~min}$; and returning to $5 \% \mathrm{~B}$ in 5 min. Solvent A was 100:0 $\mathrm{H}_{2} \mathrm{O} /$ acetonitrile (v/v) with $0.1 \%$ formic acid, and solvent $B$ was 10:90 $\mathrm{H}_{2} \mathrm{O} /$ acetonitrile (v/v) with $0.1 \%$ formic acid. Peptides were infused into the mass spectrometer via dynamic Nanospray probe (ThermoElectron Corp.) with a stainless steel emitter (Proxeon, Odense, DK). The typical spray voltage was $1.6 \mathrm{kV}$ with no sheath and auxiliary gas flow; the ion transfer tube temperature was $200^{\circ} \mathrm{C}$. The mass spectrometer was operated in data-dependent mode. The automated gain control was set to $5 \times 10^{5}$ charges and $1 \times$ $10^{4}$ charges for MS/MS at the linear ion trap analyzer. A DDA cycle consisted of the survey scan within $m / z, 300-1300$ at the
Orbitrap analyzer with target mass resolution of 60,000 (FWHM, full width at half maximum at $\mathrm{m} / \mathrm{z}$ 400) followed by MS/MS fragmentation of the five most intense precursor ions under the relative collision energy of $35 \%$ in the linear trap. Singly charged ions were excluded from MS/MS experiments, and $m / z$ of fragmented precursor ions were dynamically excluded for a further $90 \mathrm{~s}$. The ion selection threshold for triggering MS/MS experiments was set to 500 counts. An activation parameter $q$ of 0.25 and activation time of $30 \mathrm{~ms}$ were applied. PEAKS DB (version 5.3) was applied to spectra generated by LTQ-ORBITRAP-XL to screen the protein composition of the corona of the NPs. The false discovery rate was manually adjusted to zero.

To determine the total number of the LC-MS/MS spectra for all of the peptides that were attributed to a matched protein, a semi-quantitative assessment of the protein amounts was conducted using the spectral counting ( $\mathrm{SpC}$ ) method by applying the following equation ${ }^{13}$ :

$$
\mathrm{NpSpC}_{k}=\left(\frac{\left(\mathrm{SpC} / M_{\mathrm{w}}\right)_{k}}{\sum_{i=1}^{n}\left(\mathrm{SpC} / M_{\mathrm{w}}\right)_{i}}\right) \times 100
$$

where $\mathrm{NpSpCk}$ is the normalized percentage of the spectral count for protein $k, \mathrm{SpC}$ is the spectral count identified, and $\mathrm{MW}$ is the molecular weight (in $\mathrm{kDa}$ ) of protein $k$.

\section{Magnetic susceptibility}

SPIONs are initially superparamagnetic, whereas free $\mathrm{Fe}$ ions are paramagnetic. The magnetic volume susceptibility $\chi_{\text {vol }}$ of magnetite is $6 \times 10^{6}$ (SI unit), whereas that of ferritin is 0.8-2.4 $\times 10^{-4}$. This $10^{10}$ magnitude difference of the values indicates that iron oxide NPs, not Fe ions or a Fe ion-ferritin complex, would be determined by a magnetic susceptibility measurement. $^{23}$ Magnetization versus field measurements, $M(\mathrm{H})$, were performed using a MS3 magnetic susceptibility meter (Bartington Instruments Limited, Oxon, England). A MS2B dual-frequency sensor and MS2G single-frequency sensor were used for the organs and serum, respectively. The measurements were performed in triplicate at room temperature. The organs from the rat not injected with NPs were used as controls.

\section{Data analysis for biodistribution of the NPs}

All of the data are expressed as the percentage of the total $\mathrm{Fe}$ injected dose after verification of the concordance between the injected dose and the total activity observed in the organ.

\section{Results}

PVA-coated SPIONs with various surface charges (i.e., negative, positive, and neutral) were prepared for in vivo protein corona evaluations. The effective hydrodynamic diameters of positive, neutral, and negative NPs were $90 \pm 31$, 
$95 \pm 18$, and $91 \pm 22 \mathrm{~nm}$, respectively. SPIONs coated with PVA containing amino and carboxyl groups showed positive and negative charges of 13 and $-15 \mathrm{mV}$, respectively. SPIONs coated with plain PVA $(-\mathrm{OH})$ showed a slight positive charge of $6 \mathrm{mV}$ that represented a neutral particle. All types of SPIONs showed no trace of toxicity after interactions with RAW 264.7 cells (Fig. 1).

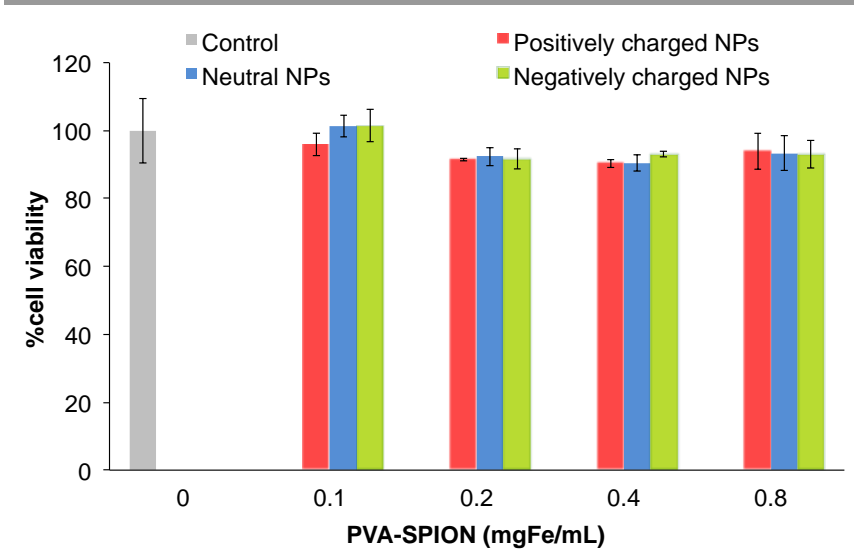

Fig. 1 The percentage cell viability of RAW 264.7 (mouse leukemic monocyte macrophage cell line) cells after incubation with positively charged, neutral, and negatively charged NPs at $37^{\circ} \mathrm{C}$ for $24 \mathrm{~h}$. No difference between cells incubated with NPs and control (no NPs) could be observed, indicating no influence of NPs on cytotoxicity.

To investigate the in vivo protein-SPION interaction, $1.4 \mathrm{~mL}(7$ $\mathrm{mg} \mathrm{Fe}$ ) of various SPIONs was injected intravenously into the rats' tails; 15 min after the injection, the SPIONs were collected from the rats' blood using a magnetic separator. To characterize the hard corona composition, the separated NPs were washed with PBS with an increasing salt content as high as $2 \mathrm{M} \mathrm{NaCl}$. The hard coronas of in vivo SPIONs with various surface charges were evaluated using LC-MS/MS techniques. The $\mathrm{NpSpC}$ values present the relative amounts of the identified proteins in the hard corona. The $\mathrm{NpSpC}$ results for all detected proteins are presented in Tables S1-S3 (in Supplementary information).

Proteins showing a relatively high amount $(\mathrm{NpSpCk}>2$ at the surface of at least one particle type) were assumed more likely to influence the biological effects of NPs, and are listed in Table 1. Without considering the amounts, the hard corona proteins on the three different NPs surfaces involved in the main biological processes were also different (Table 2).

Lower molecular weight proteins (less than $30 \mathrm{kDa}$ ) were observed more on all three different surface-charged NPs comparing with higher molecular weight proteins. The LCMS/MS results indicate that the fibrinogen-based proteins (i.e., alpha and beta chains) were significant in the in vivo composition of the protein corona (positively charged SPIONs: $\mathrm{NpSpC}$ percentages of $7.90 \pm 0.09$ and $2.75 \pm 0.04$ for the fibrinogen alpha and beta chains, respectively; neutral SPIONs: $\mathrm{NpSpC}$ percentages of $9.05 \pm 0.85,8.86 \pm 0.98$, and $7.30 \pm 0.81$ for the fibrinogen alpha, beta, and gamma chains, respectively; negatively charged SPIONs: NpSpC percentages of $4.24 \pm$ $0.00,2.26 \pm 0.00$, and $2.02 \pm 0.00$ for the fibrinogen alpha, beta, and gamma chains, respectively). Other proteins abundant at the surface of positively charged and neutral NPs, but not on negatively charged NPs, were complement C3 and alpha-2HSglycoprotein (which is involved in endocytosis, brain development, and bone tissue formation, although its exact function is poorly understood ${ }^{24}$ ). In addition, some proteins were found on neutral and negatively charged NPs but not on positively charged NPs (i.e., apolipoprotein A-II, serine/arginine-rich splicing factor 5, ficolin-1).

The surface charge of the SPIONs plays a crucial role in the type of adsorbed proteins. For instance, the apolipoprotein A-II precursor, which is crucial in mediating the transport of certain NPs through blood-brain barriers, was a significant component of the hard corona of neutral and negatively charged SPIONs, but not positively charged SPIONs in vivo $(\mathrm{NpSpC}$ of $4.85 \pm$ $0.53 \%$ and $7.15 \pm 0.00 \%$ for the neutral and negatively charged SPIONs, respectively).

For the higher molecular weight protein ranges, depending on the charge of the SPIONs, the NpSpC amounts exhibited "dual" variation; in this case, the neutral SPIONs contained significantly higher amounts of $50-70 \mathrm{kDa}$ proteins than the charged SPIONs did.

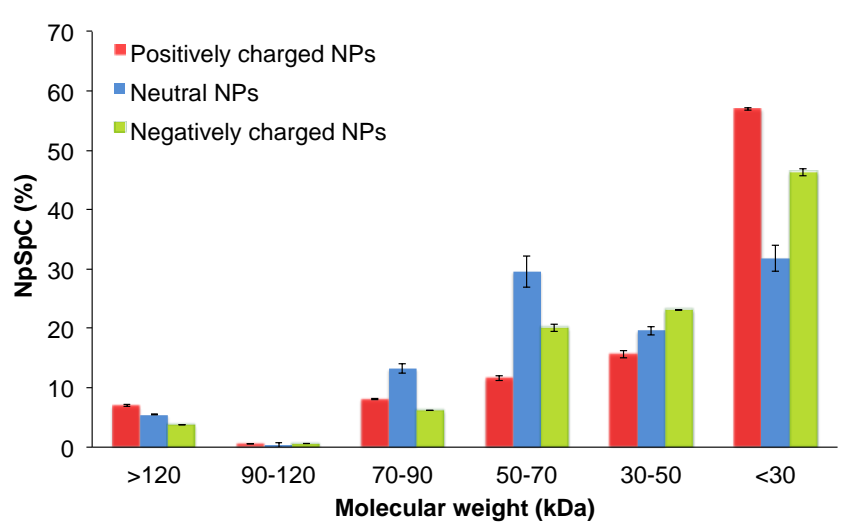

Fig. 2 Normalized spectral counts (NpSpCs) of proteins of various molecular weight ranges contained in the hard corona of the three types of charged SPIONs after injection into and recovery from mice.

The amounts of proteins in the hard corona of charged NPs increased with decreasing molecular weight. The relative amounts of $90-120 \mathrm{kDa}$ proteins were lowest, whereas the amounts of protein with molecular weight less than $30 \mathrm{kDa}$ were highest. However, the amounts of proteins slightly increased among proteins larger than $120 \mathrm{kDa}$ (Fig. 2). 
Table 1: Representative hard corona proteins associated with positively charged, neutral, and negatively charged SPIONs after in vitro and in vivo treatments, as identified by LC-MS/MS ${ }^{\text {a }}$, the standard deviations were obtained from two individual tests (the three most adsorbed proteins per charge and the environment are in bold face).

\begin{tabular}{|c|c|c|c|c|c|c|c|c|}
\hline \multirow[t]{2}{*}{ Accession } & \multirow[t]{2}{*}{$\begin{array}{l}\text { MW } \\
\text { (Da) }\end{array}$} & \multirow[t]{2}{*}{ Protein } & \multicolumn{2}{|c|}{$\begin{array}{c}\text { Average NpSpC on } \\
\text { positively charged } \\
\text { SPIONs } \\
\end{array}$} & \multicolumn{2}{|c|}{$\begin{array}{c}\text { Average NpSpC on } \\
\text { neutral SPIONs }\end{array}$} & \multicolumn{2}{|c|}{$\begin{array}{c}\text { Average NpSpC on } \\
\text { negatively charged } \\
\text { SPIONs } \\
\end{array}$} \\
\hline & & & in vitro & in vivo & in vitro & in vivo & in vitro & in vivo \\
\hline P02770|ALBU & 68731 & Serum albumin & $1.54 \pm 0.04$ & $2.39 \pm 0.33$ & $2.92 \pm 0.02$ & $1.08 \pm 0.12$ & $8.49 \pm 0.62$ & $1.78 \pm 0.00$ \\
\hline Q63207|FA10 & 54265 & $\begin{array}{l}\text { Coagulation factor } \\
\mathrm{X}\end{array}$ & $5.07 \pm 0.15$ & $2.20 \pm 0.02$ & $4.01 \pm 0.04$ & $4.27 \pm 0.71$ & & $5.65 \pm 0.00$ \\
\hline P02650|APOE & 35753 & Apolipoprotein E & $\begin{array}{c}10.65 \pm \\
0.32\end{array}$ & $9.99 \pm 0.11$ & $8.42 \pm 0.06$ & $4.14 \pm 0.46$ & & $5.72 \pm 0.00$ \\
\hline Q62740|SPP24 & 23170 & $\begin{array}{l}\text { Secreted } \\
\text { phosphoprotein } 24\end{array}$ & $0.91 \pm 0.03$ & $7.07 \pm 0.99$ & $0.73 \pm 0.01$ & $5.15 \pm 0.01$ & & $4.41 \pm 0.00$ \\
\hline P02091|HBB1 & 15979 & $\begin{array}{l}\text { Hemoglobin subunit } \\
\text { beta-1 }\end{array}$ & $6.62 \pm 0.21$ & $13.04 \pm 0.16$ & $4.19 \pm 0.04$ & $6.94 \pm 0.77$ & & $8.96 \pm 0.01$ \\
\hline P01946|HBA & 15329 & $\begin{array}{l}\text { Hemoglobin subunit } \\
\text { alpha-1/2 }\end{array}$ & $6.90 \pm 0.21$ & $16.50 \pm 1.18$ & $4.37 \pm 0.04$ & $8.44 \pm 0.93$ & & $9.33 \pm 0.00$ \\
\hline P01026|CO3 & 186459 & Complement C3 & $0.80 \pm 0.02$ & $5.43 \pm 0.06$ & $0.90 \pm 0.01$ & $2.63 \pm 0.36$ & & \\
\hline Q62930|CO9 & 62281 & $\begin{array}{l}\text { Complement } \\
\text { component } \mathrm{C} 9\end{array}$ & $4.42 \pm 0.13$ & $0.48 \pm 0.01$ & $5.10 \pm 0.04$ & $0.60 \pm 0.06$ & & \\
\hline P24090|FETUA & 37982 & $\begin{array}{l}\text { Alpha-2-HS- } \\
\text { glycoprotein }\end{array}$ & $5.01 \pm 0.16$ & $1.57 \pm 0.02$ & $4.84 \pm 0.04$ & $1.95 \pm 0.22$ & & \\
\hline P04639|APOA1 & 30062 & Apolipoprotein A-I & $11.25 \pm 0.34$ & $0.99 \pm 0.01$ & $\begin{array}{c}11.12 \pm \\
0.08\end{array}$ & $4.30 \pm 0.48$ & & \\
\hline P06399|FIBA & 86686 & $\begin{array}{l}\text { Fibrinogen alpha } \\
\text { chain }\end{array}$ & & $7.90 \pm 0.09$ & & $9.05 \pm 0.85$ & & $4.24 \pm 0.00$ \\
\hline P14480|FIBB & 54235 & $\begin{array}{l}\text { Fibrinogen beta } \\
\text { chain }\end{array}$ & & $2.75 \pm 0.04$ & & $8.86 \pm 0.98$ & & $2.26 \pm 0.00$ \\
\hline P11517|HBB2 & 15982 & $\begin{array}{l}\text { Hemoglobin subunit } \\
\text { beta-2 }\end{array}$ & & $16.76 \pm 0.20$ & & $2.67 \pm 3.77$ & & $\begin{array}{c}10.23 \pm \\
0.00\end{array}$ \\
\hline P08932|KNT2 & 47704 & T-kininogen 2 & & & $3.50 \pm 0.03$ & $0.18 \pm 0.25$ & $6.80 \pm 0.49$ & \\
\hline P23680|SAMP & 26176 & $\begin{array}{l}\text { Serum amyloid P- } \\
\text { component }\end{array}$ & $6.07 \pm 0.76$ & & $5.75 \pm 0.04$ & & & \\
\hline P08494|MGP & 12037 & Matrix Gla protein & & $2.47 \pm 0.03$ & & $3.07 \pm 0.34$ & & \\
\hline P05371|CLUS & 51375 & Clusterin & & & $0.65 \pm 0.00$ & $2.88 \pm 0.32$ & & \\
\hline P13635|CERU & 120841 & Ceruloplasmin & & & $2.08 \pm 0.02$ & & $4.83 \pm 0.35$ & \\
\hline P01048|KNT1 & 47775 & T-kininogen 1 & & & $2.45 \pm 0.01$ & & $5.43 \pm 0.40$ & \\
\hline P02680|FIBG & 50633 & $\begin{array}{l}\text { Fibrinogen gamma } \\
\text { chain }\end{array}$ & & & & $7.30 \pm 0.81$ & & $2.02 \pm 0.00$ \\
\hline Q9WTS8|FCN1 & 36627 & Ficolin-1 & & & & $2.52 \pm 0.28$ & & $5.02 \pm 0.00$ \\
\hline P04638|APOA2 & 11439 & Apolipoprotein A-II & & & & $4.85 \pm 0.53$ & & $7.15 \pm 0.00$ \\
\hline Q9EPH1|A1BG & 56479 & $\begin{array}{l}\text { Alpha-1B- } \\
\text { glycoprotein }\end{array}$ & & & & & $5.74 \pm 0.42$ & $1.27 \pm 0.25$ \\
\hline Q01177|PLMN & 90536 & Plasminogen & $2.22 \pm 0.23$ & & & & & \\
\hline P18292|THRB & 70412 & Prothrombin & $2.70 \pm 0.08$ & & & & & \\
\hline P63259|ACTG & 41793 & $\begin{array}{l}\text { Actin_cytoplasmic } \\
2\end{array}$ & $2.53 \pm 0.07$ & & & & & \\
\hline Р60711|АСТВ & 41737 & $\begin{array}{l}\text { Actin_cytoplasmic } \\
1\end{array}$ & $2.54 \pm 0.08$ & & & & & \\
\hline P16296|FA9 & 31447 & $\begin{array}{l}\text { Coagulation factor } \\
\text { IX (Fragment) }\end{array}$ & $2.69 \pm 0.08$ & & & & & \\
\hline Q64119|MYL6 & 16975 & $\begin{array}{l}\text { Myosin light } \\
\text { polypeptide } 6\end{array}$ & $3.74 \pm 0.11$ & & & & & \\
\hline Q68FR2|BIN2 & 55118 & $\begin{array}{l}\text { Bridging integrator } \\
2\end{array}$ & & & $2.12 \pm 0.01$ & & & \\
\hline
\end{tabular}




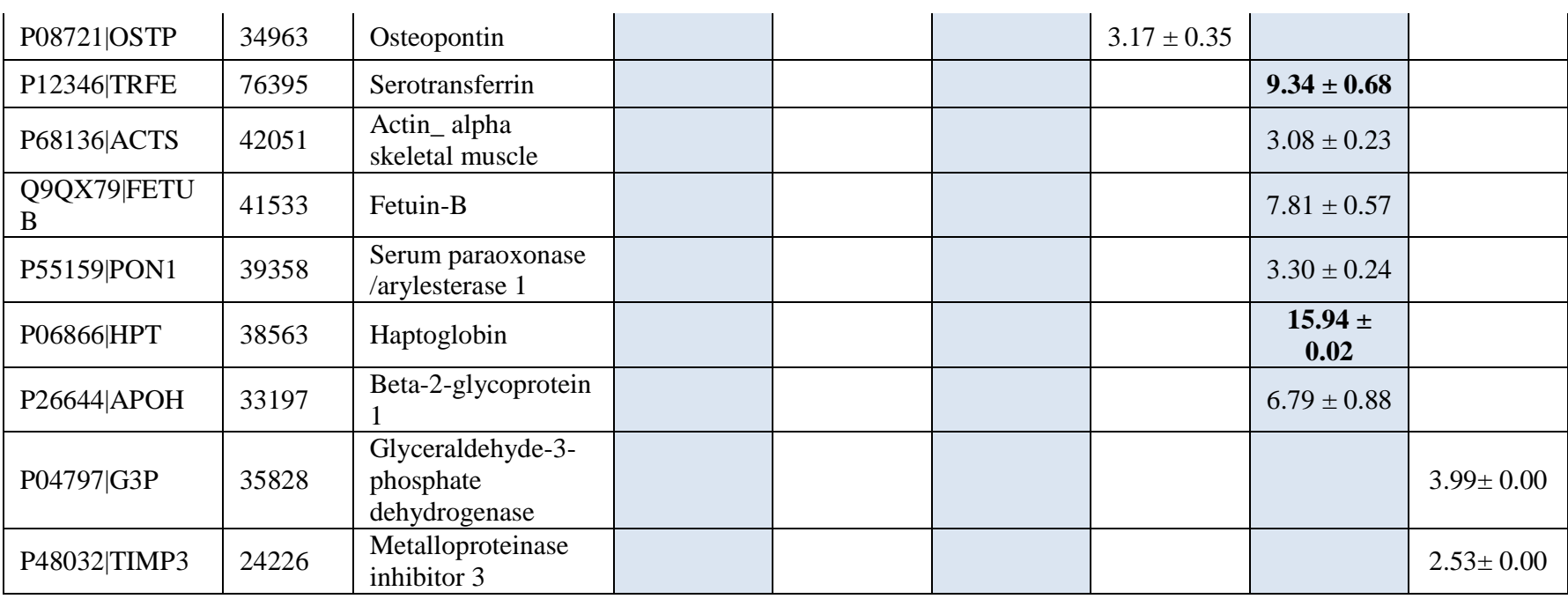

${ }^{a}$ The normalized spectral counts (NSpCs) were calculated for each protein according to Equation 1. This table contains only the most significant hits; the full list of the most abundant proteins identified by LC-MS/MS is provided in Tables S1 and S6 in the additional file.

The numbers of different proteins that compose the protein coronas are different for the different charges. The positively charged NPs contained the lowest number of different proteins (32) whereas the neutral and negatively charged NPs contained 55 and 51 different proteins, respectively. All three surfaces shared up to $32 \%$ proteins, while the proteins that bound specifically on the positively charged, neutral, and negatively charged NPs were 7\%, 27\%, and 19\%, respectively (Fig. 3).

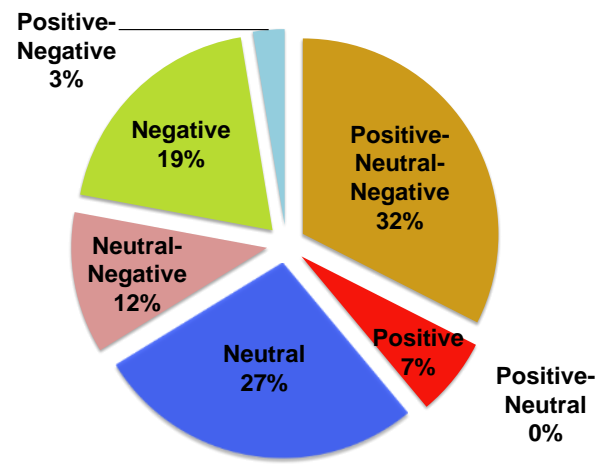

Fig 3 Proportions (by number) of all proteins identified in the hard corona of NPs with different surface charges (positive, neutral, negative) after injection into and recovery from rats.

None of the proteins was present on both positive and neutral NPs, and only a few proteins bound both positively and negatively charged NPs (these had NpSpCs < 2).

In addition to types of proteins, the amounts of each type also influence the biological effect in vivo. Figure 4 shows the relative amount of each type of protein that was observed on each type of NPs. As shown in Fig. 4, the corona composition of the positively charged SPIONs consisted of proteins that were also detected on the neutral NPs and partially on negatively charged NPs; however, the latter two contained many other proteins. In addition, the 10 most abundant proteins in the three different protein coronas were different.

The LC-MS/MS results indicate that the composition of the protein coronas of all three charged NPs differed between the in vivo and in vitro experiments, despite having the same protein source (i.e., rat serum) under the same standard physiological temperature $\left(37^{\circ} \mathrm{C}\right)$ and incubation time (Table 1). Serum albumin was the only important protein that was observed on all of the NPs in vivo and in vitro. However, a relatively high amount of serum albumin was only measured for the negatively charged NPs in vitro, whereas the level was low for all the other NPs and conditions. The second group of most abundant proteins at the NP surface were coagulation factor $\mathrm{X}$, secreted phosphoprotein 24, hemoglobin subunit beta-1, and alpha-1/2 and Apolipoprotein $\mathrm{E}$ which were only absent from the negatively charged NPs for the in vitro incubation. Of note, the detection of factor $\mathrm{X}$ in serum appeared to be because not all factor $\mathrm{X}$ was consumed in the conversion of prothrombin into thrombin. ${ }^{25}$ Complement C3, complement component C9, Apolipoprotein A-I and alpha-2HS-glycoprotein were detected under both in vitro and in vivo on positively charged and neutral NPs, but not on negatively charged NPs. 
Table 2 Hard corona proteins from the in vivo study that are involved in the major biological processes (based on the information from www.uniprot.org and www.string-db.org).

\begin{tabular}{|c|c|c|c|}
\hline Biological process & Positive & Neutral & Negative \\
\hline Blood coagulation & $\begin{array}{l}\text { Coagulation factor VII } \\
\text { Fibrinogen alpha chain } \\
\text { Fibrinogen beta chain } \\
\text { Fibrinogen gamma chain }\end{array}$ & $\begin{array}{c}\text { Coagulation factor XIII A chain } \\
\text { Prothrombin } \\
\text { Coagulation factor VII } \\
\text { Coagulation factor IX (Fragment) } \\
\text { Fibrinogen alpha chain } \\
\text { Fibrinogen beta chain } \\
\text { Fibrinogen gamma chain } \\
\text { Kininogen-1 }\end{array}$ & $\begin{array}{c}\text { Prothrombin } \\
\text { Coagulation factor VII } \\
\text { Coagulation factor IX (Fragment) } \\
\text { Fibrinogen alpha chain } \\
\text { Fibrinogen beta chain } \\
\text { Fibrinogen gamma chain } \\
\text { Growth arrest-specific protein } 6 \\
\text { Vitamin K-dependent protein C }\end{array}$ \\
\hline Hemostasis & $\begin{array}{l}\text { Coagulation factor VII } \\
\text { Fibrinogen alpha chain } \\
\text { Fibrinogen beta chain } \\
\text { Fibrinogen gamma chain }\end{array}$ & $\begin{array}{c}\text { Coagulation factor XIII A chain } \\
\text { Prothrombin } \\
\text { Coagulation factor VII } \\
\text { Coagulation factor IX (Fragment) } \\
\text { Fibrinogen alpha chain } \\
\text { Fibrinogen beta chain } \\
\text { Fibrinogen gamma chain } \\
\text { Kininogen-1 } \\
\text { Vitamin K-dependent protein S }\end{array}$ & $\begin{array}{c}\text { Prothrombin } \\
\text { Coagulation factor VII } \\
\text { Coagulation factor IX (Fragment) } \\
\text { Fibrinogen alpha chain } \\
\text { Fibrinogen beta chain } \\
\text { Fibrinogen gamma chain } \\
\text { Growth arrest-specific protein } 6 \\
\text { Vitamin K-dependent protein C } \\
\text { Vitamin K-dependent protein S }\end{array}$ \\
\hline $\begin{array}{l}\text { Acute inflammatory } \\
\text { response }\end{array}$ & $\begin{array}{l}\text { Complement C3 } \\
\text { Fibronectin } \\
\text { Murinoglobulin-1 }\end{array}$ & $\begin{array}{c}\text { Complement C3 } \\
\text { Prothrombin } \\
\text { Fibronectin } \\
\text { Kininogen-1 } \\
\text { T-kininogen } 2 \\
\text { Murinoglobulin-1 }\end{array}$ & $\begin{array}{c}\text { Complement C3 } \\
\text { C-reactive protein } \\
\text { Prothrombin } \\
\text { Fibronectin } \\
\text { Lipopolysaccharide-binding protein } \\
\text { Murinoglobulin-1 }\end{array}$ \\
\hline $\begin{array}{l}\text { Complement } \\
\text { activation }\end{array}$ & $\begin{array}{c}\text { Complement C3 } \\
\text { Complement component C9 }\end{array}$ & $\begin{array}{c}\text { Complement C3 } \\
\text { Complement component C9 } \\
\text { Ficolin-1 }\end{array}$ & $\begin{array}{c}\text { Complement C3 } \\
\text { Complement component C9 } \\
\text { Ficolin-1 } \\
\text { Ficolin-2 }\end{array}$ \\
\hline $\begin{array}{c}\text { Immune system } \\
\text { process }\end{array}$ & $\begin{array}{c}\text { Complement C3 } \\
\text { Complement component C9 } \\
\text { Hemoglobin subunit beta-2 } \\
\text { Osteopontin } \\
\text { Stomatin-like protein } 2\end{array}$ & $\begin{array}{c}\text { Apolipoprotein A-IV } \\
\text { Complement C3 } \\
\text { Complement component C9 } \\
\text { Ficolin-1 } \\
\text { Hemoglobin subunit beta-2 } \\
\text { 1-phosphatidylinositol 4_5-bisphosphate } \\
\text { phosphodiesterase gamma-1 } \\
\text { 1-phosphatidylinositol 4_5-bisphosphate } \\
\text { phosphodiesterase gamma-2 } \\
\text { Sperm flagellar protein } 2 \\
\text { Osteopontin }\end{array}$ & $\begin{array}{c}\text { Apolipoprotein A-IV } \\
\text { Complement C3 } \\
\text { Complement component C9 } \\
\text { Ficolin-1 } \\
\text { Ficolin-2 } \\
\text { Lipopolysaccharide-binding protein } \\
\text { Hemoglobin subunit beta-2 } \\
\text { Myosin-9 } \\
\text { Osteopontin }\end{array}$ \\
\hline Transport & $\begin{array}{c}\text { Serum albumin } \\
\text { Apolipoprotein A-I (lipid transport) } \\
\text { Apolipoprotein E } \\
\text { (positive regulation of lipid transport, } \\
\text { vesicle-mediated transport) } \\
\text { Hemoglobin subunit beta-2 } \\
\text { (oxygen transport) } \\
\text { Band } 3 \text { anion transport protein } \\
\text { (inorganic anionic transport) } \\
\text { Stromal interaction molecule } 1 \text { (divalent } \\
\text { inorganic/metal cation transport) } \\
\text { Stomatin-like protein } 2 \\
\text { (divalent inorganic/metal cation } \\
\text { transport, intracellular transport) }\end{array}$ & $\begin{array}{l}\text { Serum albumin } \\
\text { Apolipoprotein A-I (lipid transport) } \\
\text { Apolipoprotein A-II (negative regulation of } \\
\text { transmembrane transport } \\
\text { Apolipoprotein A-IV (lipid transport) } \\
\text { Apolipoprotein E (positive regulation of } \\
\text { lipid transport, vesicle-mediated transport) } \\
\text { Clusterin (manganese ion transmembrane } \\
\text { transport) } \\
\text { Prothrombin (positive regulation of } \\
\text { intracellular transport) } \\
\text { Glutamate receptor_ionotropic kainate } 4 \\
\text { (ion transmembrane transport) } \\
\text { Glutamate receptor_ionotropic kainite } 5 \\
\text { (ion transmembrane transport) } \\
\text { Hemoglobin subunit beta-2 (oxygen } \\
\text { transport) } \\
\text { 1-phosphatidylinositol 4_5-bisphosphate } \\
\text { phosphodiesterase gamma-2 (positive } \\
\text { transporter activity) }\end{array}$ & $\begin{array}{c}\text { Serum albumin } \\
\text { Apolipoprotein A-I (lipid transport) } \\
\text { Apolipoprotein A-II (negative } \\
\text { regulation of transmembrane } \\
\text { transport) } \\
\text { Apolipoprotein A-IV (lipid transport) } \\
\text { Apolipoprotein E (positive regulation } \\
\text { of lipid transport, vesicle-mediated } \\
\text { transport) } \\
\text { Cadherin-1 (positive regulation of } \\
\text { intracellular transport) } \\
\text { Prothrombin (positive regulation of } \\
\text { intracellular transport) } \\
\text { Growth arrest-specific protein } 6 \\
\text { (negative regulation of intracellular } \\
\text { protein transport) } \\
\text { Lipopolysaccharide-binding protein } \\
\text { (lipopolysaccharide transport) } \\
\text { Hepatic triacylglycerol lipase (lipid } \\
\text { transport) }\end{array}$ \\
\hline
\end{tabular}




\begin{tabular}{|c|c|c|c|}
\hline & & Serotransferrin (iron ion transport) & Myosin-9 (sodium ion transport) \\
\hline $\begin{array}{l}\text { Metabolic process } \\
\text { (e.g., protein, lipid, } \\
\text { carbohydrate) }\end{array}$ & $\begin{array}{c}\text { Alpha-2-HS-glycoprotein } \\
\text { Apolipoprotein A-I } \\
\text { Apolipoprotein E } \\
\text { Complement C3 } \\
\text { Complement component C9 } \\
\text { Glyceraldehyde-3-phosphate } \\
\text { dehydrogenase } \\
\text { Hemoglobin subunit beta-2 } \\
\text { [Pyruvate dehydrogenase [lipoamide]] } \\
\text { kinase isozyme 2_ mitochondrial } \\
\text { Sialate } O \text {-acetylesterase } \\
\text { Stomatin-like protein } 2\end{array}$ & $\begin{array}{c}\text { Alpha-2-HS-glycoprotein } \\
\text { Apolipoprotein A-I } \\
\text { Apolipoprotein A-II } \\
\text { Apolipoprotein A-IV } \\
\text { Apolipoprotein A-V } \\
\text { Apolipoprotein E } \\
\text { Complement C3 } \\
\text { Complement component C9 } \\
\text { Eukaryotic translation initiation factor 3 } \\
\text { subunit B } \\
\text { Prothrombin } \\
\text { Ficolin-1 } \\
\text { Glyceraldehyde-3-phosphate dehydrogenase } \\
\text { Hemoglobin subunit beta-2 } \\
\text { 1-phosphatidylinositol 4_5-bisphosphate } \\
\text { phosphodiesterase gamma-1 } \\
\text { 1-phosphatidylinositol 4_5-bisphosphate } \\
\text { phosphodiesterase gamma-2 } \\
\text { Serine/arginine-rich splicing factor 2 } \\
\text { Serine/arginine-rich splicing factor 5 } \\
\text { Metalloproteinase inhibitor 3 }\end{array}$ & $\begin{array}{c}\text { Alpha-2-HS-glycoprotein } \\
\text { Apolipoprotein A-I } \\
\text { Apolipoprotein A-II } \\
\text { Apolipoprotein A-IV } \\
\text { Apolipoprotein E } \\
\text { Complement C3 } \\
\text { Complement component C9 } \\
\text { Cadherin-1 } \\
\text { Prothrombin } \\
\text { Ficolin-1 } \\
\text { Glyceraldehyde-3-phosphate } \\
\text { dehydrogenase } \\
\text { Growth arrest-specific protein } 6 \\
\text { Heparanase } \\
\text { Insulin-like growth factor-binding } \\
\text { protein 5 } \\
\text { Inter-alpha-trypsin inhibitor heavy } \\
\text { chain H3 } \\
\text { Lipopolysaccharide-binding protein } \\
\text { Hepatic triacylglycerol lipase } \\
\text { Lipoprotein lipase } \\
\text { Hemoglobin subunit beta-2 } \\
\text { Myosin-9 } \\
\text { Serine/arginine-rich splicing factor 5 } \\
\text { Sialate O-acetylesterase } \\
\text { Metalloproteinase inhibitor } 3\end{array}$ \\
\hline
\end{tabular}



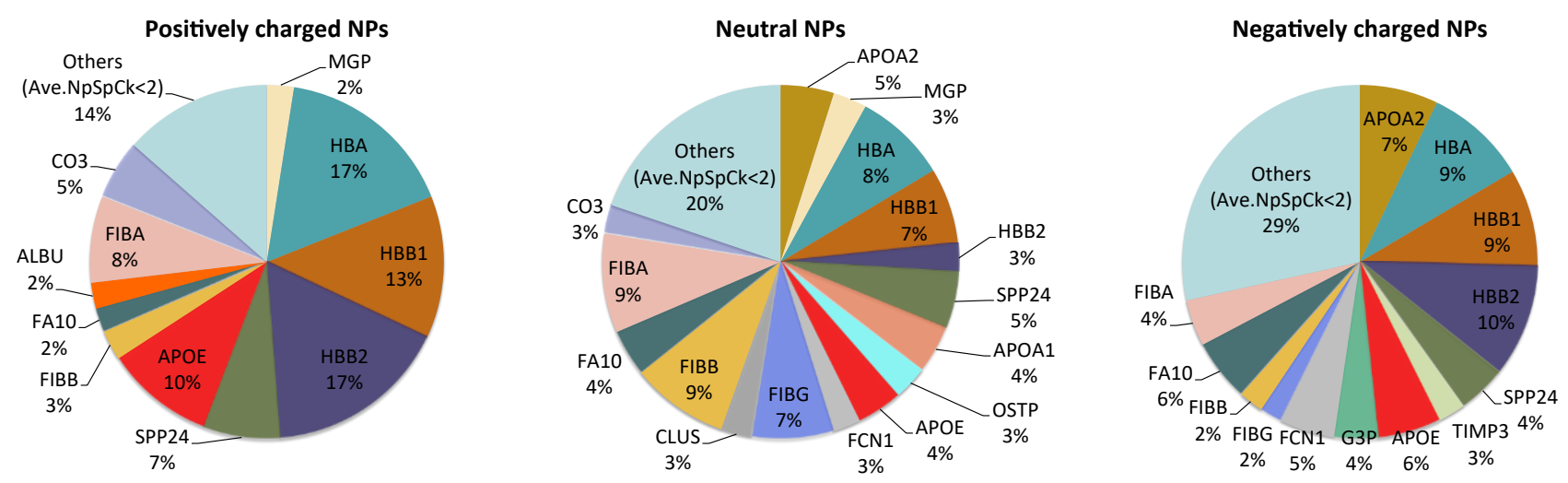

Fig. 4. Percentage of relative amount of all hard corona proteins from in vivo study that were observed on each type of NPs.

The protein coronas formed in vivo contained considerably higher amounts of low molecular weight $(<30 \mathrm{kDa})$ proteins compared with the in vitro coronas (Fig. 5). In contrast, the 30$50 \mathrm{kDa}$ proteins were more abundant in the hard coronas formed in vitro than in those formed in vivo. For the higher molecular weight (i.e., 50-70 $\mathrm{kDa}$ ) protein ranges, depending on the charge of the SPIONs, the NpSpC amounts exhibited "dual" variation; in this case, the neutral SPIONs contained significantly higher amounts of proteins in the molecular range of $50-70 \mathrm{kDa}$ (which contains majority of the important proteins) in vivo, whereas the opposite trend was observed for both the positively and negatively charged SPIONs.

Figure 6 presents the differences in the proteins adsorbed to each surface charge type in the in vivo and in vitro conditions. For hard coronas on neutral NPs, $50 \%$ of the proteins were observed in both the in vitro and in vivo experiments, $17 \%$ were observed in vitro, and $33 \%$ were observed in vivo. For the positively charged NPs, $48 \%$ of the hard corona proteins were observed in both the in vitro and in vivo experiments, whereas $33 \%$ and $19 \%$ of the proteins were observed in only the in vitro or in vivo experiments, respectively. In contrast, only $8 \%$ of the hard corona proteins on the negatively charged NPs were observed in both the in vitro and in vivo experiments, whereas the percentage of identified proteins in only the in vitro or in vivo experiments increased to $38 \%$ and $54 \%$, respectively.

Figure 7 shows the biodistribution of SPIONs in rat organs 15 min after injection of $7 \mathrm{mg} \mathrm{Fe}$ of SPIONs. We were able to recover almost $100 \%$ of the injected NPs $(94.7 \pm 9.88 \%, 101.4$ $\pm 3.26 \%$, and $103.05 \pm 4.28 \%$ for the positively charged, neutral, and negatively charged NPs, respectively). The serum contained $83.2 \pm 3.68 \%$ of the neutral NPs and $83.39 \pm 3.19 \%$ of the negatively charged NPs, a.

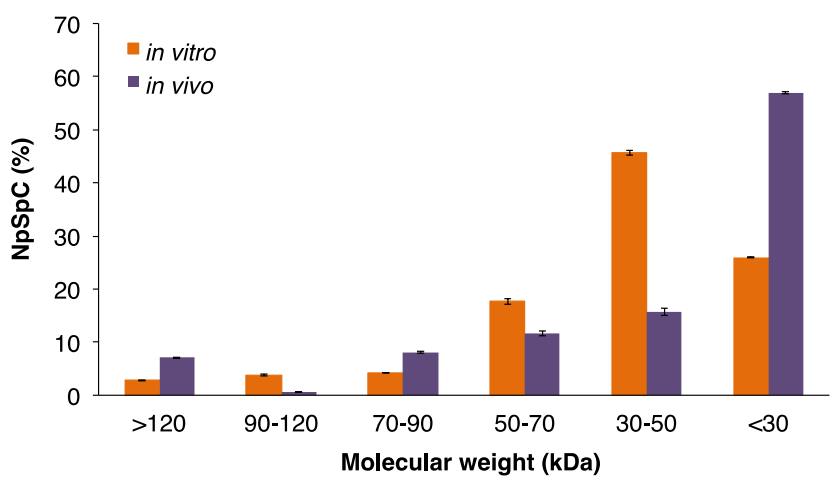

b.

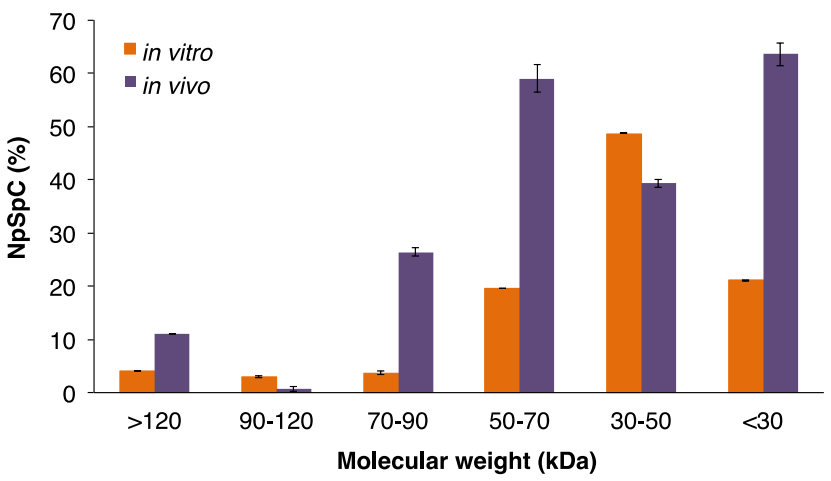

c.

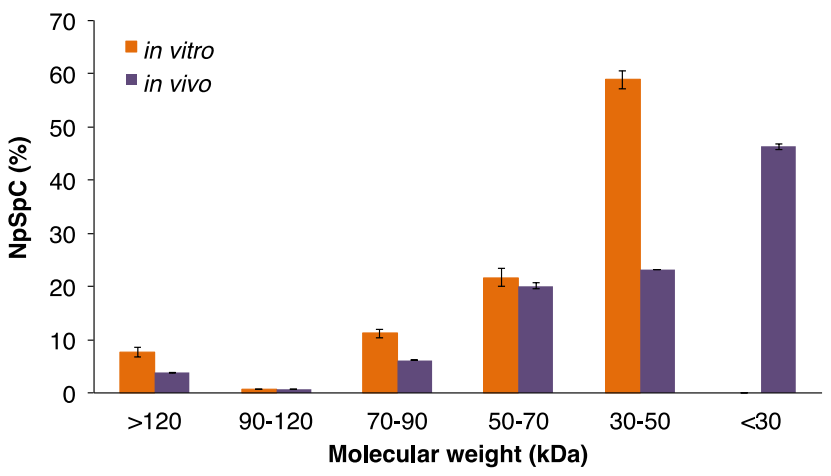

Fig. 5 Normalized spectral counts (NpSpCs) of proteins of various molecular weight ranges. The proteins contained in the hard corona of the in vitro and in vivo samples on positively charged (a), neutral (b), and negatively charged (c) NPs. 

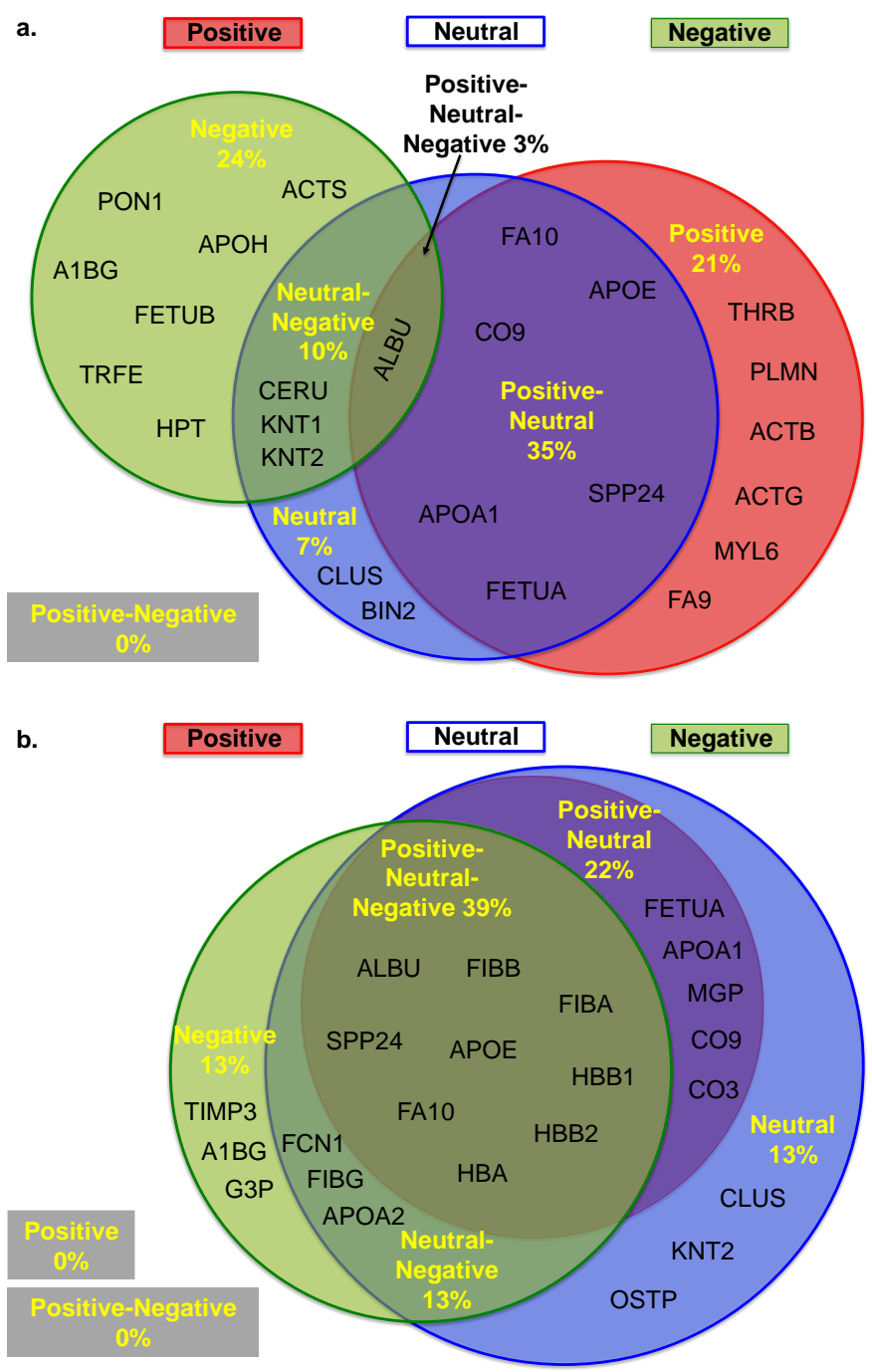

Fig. 6 Hard corona proteins of in vitro and in vivo experiments. In vitro (a) and in vivo (b) protein adsorption to NPs of different surface charges injected into and recovered from rats (MS analysis of NP tightly bound proteins). This figure contains only the most significant proteins (Table 1). The protein composition of the hard corona on the in vivo NPs is different from the that on the in vitro NPs.

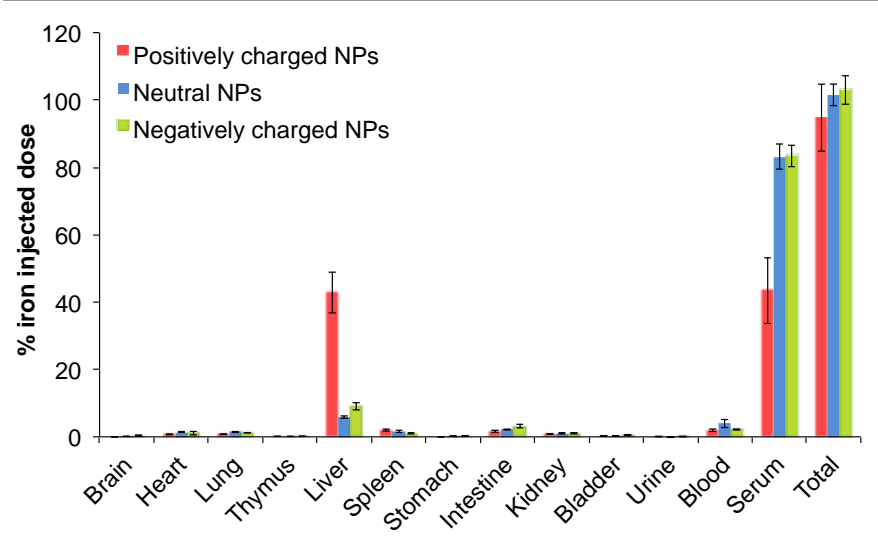

Fig. 7 The biodistribution of NPs with three different surface charges is graphically represented as a measure of the percentage of the Fe injected dose recovered in rat organs. At $15 \mathrm{~min}$ after injection of $7 \mathrm{mg} \mathrm{Fe}$ of SPIONs, the positively charged NPs localized mainly in the liver, while the neutral and negatively charged NPs were still mainly observed in serum. The data represent triplicate measurements of $n=3$.

which was twice the proportion of the positively charged NPs $(43.5 \pm 9.8 \%)$. In contrast, the amount of NPs in blood cells did not differ much by charge $(2-4 \%)$. This reveals a tendency towards higher blood circulation time for neutral and negatively charged NPs compared with positively charged NPs. Interestingly, within $15 \mathrm{~min}, 42.8 \pm 6.14 \%$ of the positively charged NPs localized to the liver, which is four times the proportions of neutral $(5.9 \pm 0.41 \%)$ and negatively charged NPs $(9.0 \pm 1.04 \%)$. Only $1-2 \%$ of NPs were observed in the heart, the lung, the spleen $(2.1 \pm 0.36 \%, 1.6 \pm 0.36 \%$, and $0.94 \pm$ $0.14 \%$ for positively charged, neutral and negatively charged NPs, respectively) and the kidney. Negligible amounts of NPs $(0-0.3 \%$ of the injected dose) were observed in the brain, the stomach, the urine, the bladder, and the thymus. Urine fractions from the rats injected with NPs were brownish (data not shown); however, no magnetization was observed in the brownish urine samples, which indicates an absence of SPIONs in the urine. The brownish color resulted from the aggregation of urine pigment with the excreted PVA polymer. ${ }^{26}$

\section{Discussion}

Determination of the protein corona composition is still a very challenging task because the adsorption process is dynamic and the composition depends very strongly on the local environment, including protein concentration, $\mathrm{pH}$, ionic strength, and the presence of other biomolecules such as enzymes. ${ }^{27} \mathrm{~A}$ detailed description of this problem is given in the paper from Del Pino et al. ${ }^{28}$ It is also well known that the hard corona can vary significantly, changing from a protein composition appropriate to in vitro cell studies to the protein composition present during in vivo studies. ${ }^{13}$

Therefore, from our knowledge, it is impossible to know the correct protein corona composition on NPs that are in contact with a cell or in the blood stream in vivo. All experimental methods to date influence the composition, and it will be difficult to use these results to explain the behavior of NPs in vivo or in cell culture. Nevertheless, existing methods as well as the method presented here allow detection of differences in the corona composition as a function of the surface charge, and differences in the uptake and biodistribution of the NPs. This allows discussion of the roles of the different proteins in the biological behavior of inorganic NPs.

The variations in the surface charge of these three NPs confirmed the successful coating of polymer onto the SPION surface. The concentration of up to $0.8 \mathrm{mg} \mathrm{Fe} / \mathrm{mL}$ without cytotoxicity in RAW 264.7 cells revealed the potential of PVASPIONs in biomedical applications, such as for magnetic resonance imaging. ${ }^{29}$ The composition of the protein corona, and not the protein amount or number of different proteins, must determine the uptake of the particles by the liver and the blood residence time. NPs larger than $50 \mathrm{~nm}$ are generally 
taken up quickly by the liver reticuloendothelial system cells, and have limited uptake into lymph and bone. ${ }^{30}$

We speculate that one or more of the proteins that adsorb only on the neutral and negatively charged NPs lead to an increase in the blood residence time. Candidates for this role include the apolipoproteins A-II; prior literature on the effects of apolipoprotein on drug delivery suggest these proteins may promote circulation time in the bloodstream. ${ }^{31}$ Interestingly, apolipoproteins are generally considered a factor that prolongs NPs time in the bloodstream, but when examined in more detail they show slightly different roles in biological systems. Apolipoprotein A-II may stabilize high-density lipoprotein (HDL) structure by its association with lipid, and so affect HDL metabolism, whereas apolipoprotein $\mathrm{E}$ mediates the binding, internalization, and catabolism of lipoprotein particles. ${ }^{32,} 33$ Apolipoprotein E can serve as a ligand for the low-density lipoprotein (LDL) (Apo B/E) receptor and for the specific Apo$\mathrm{E}$ receptor (chylomicron remnant) in hepatic tissues. The amount of apolipoprotein $\mathrm{E}$ in the hard corona of the positively charged NPs was twice the amount in the corona of neutral and negatively charged NPs, while the uptake of the positively charged NPs in the liver was correspondingly much more than the uptake of neutral and negatively charged NPs. This is a good example of the importance of each protein and how the amount of each protein in the hard corona can affect the biological system.

For most proteins, adsorption differed, depending strongly on the charge and environment (in vivo or in vitro). For instance, the fibrinogen-based proteins (i.e., alpha chain, beta chain) were completely absent from the hard corona composition of the SPIONs in vitro, regardless of their surface charges, whereas they formed a significant component of the in vivo protein corona. Importantly, fibrinogen was not detected in the hard corona of SPIONs in vitro (although they were abundant in vivo). This is expected because serum lacks almost all coagulation factors, particularly fibrinogen (all fibrinogen molecules are used to form fibrin clot). This result is direct evidence for the specificity of our results. A second example of protein differences between in vitro and in vivo is the apolipoprotein A-II precursor: in contrast to the in vivo results, there was no detectable trace of this protein in the in vitro hard corona. In addition, the $\mathrm{NpSpC}$ amount of alpha-2-HSglycoprotein was considerably reduced in vivo compared with in vitro for the hard corona of the positively charged and neutral SPIONs.

Interestingly, the number of different proteins that composed the hard corona also differed substantially between in vitro and in vivo conditions. In all of the in vitro investigations, the positively charged NPs contained a considerably higher number of different proteins than the negatively charged NPs. In contrast, the opposite results were observed for the in vivo evaluations: the positively charged NPs contained the fewest different proteins (Fig. 3). The lowest percentage (3\%) of proteins (Anionic trypsin-1 and Sialate O-acetylesterase which had NpSpCs < 1.5) was shared between the positively charged and negatively charged NPs. The lack of proteins shared between the positively charged and neutral NPs implied that positively charged NPs would behave differently (have a different biodistribution) than neutral and negatively charged NPs. In addition, the fact that $12 \%$ of the proteins were shared between the neutral and negatively charged NPs implied a similarity in the biodistributions of these two NPs. This interpretation was confirmed by the biodistribution results. The biodistribution measurements revealed a high uptake in the liver for the positively charged NPs (40\% after $15 \mathrm{~min}$ ) and a very low uptake for the neutral and negatively charged NPs. In contrast, neutral and negatively charged NPs were more abundant than positively charged NPs in the serum (Fig. 7). This observation is in contradiction to statements that negatively charged particles adsorb less protein ${ }^{13}$ and that therefore they have a longer residence time.

It is important to take care in interpreting our results for two reasons. First, the hard corona of the positively charged NPs was determined from particles, which were still circulating in the blood. This means we do not know the protein composition of the hard corona of the other $50 \%$ of particles, which were taken up by monocytes or macrophages. These could be different from the particles in blood. Second, we only examined the composition of the hard protein corona. The weakly bound proteins must also have an influence on the biological behavior, and this influence is still unknown.

\section{Conclusions}

Although we recognize that the observed composition would not be exactly the protein corona composition in vivo or in vitro, we believe the protein corona composition assessed from particles that had spent $15 \mathrm{~min}$ in blood circulation in living rats should be very similar to the true in vivo composition. Because the treatments of the samples were very similar, we believe that the results presented in this paper reflect the composition of the protein corona in a very realistic manner and that the observed differences between the in vivo and in vitro results are significant and important for the further discussion of the behavior of inorganic nanoparticles in medical applications.

The protein-NPs complex was separated from ex vivo sera by using a high magnetic field gradient magnetic reactor. The SPION core of PVA-coated NPs did not affect particle biodistribution (or did so minimally) and, most likely, the core particles were protected by PVA molecules against direct interaction with plasma proteins and cells. The information from ex vivo protein adsorption and biodistribution studies provides better overall understanding of NPs in vivo, from the NPs-protein interaction to the physiological aspects. Our results regarding the composition of the protein hard corona show very clearly that the composition depends on the initial surface charge of the particles. In general, neutral particles show the highest number of different proteins both in vitro and in vivo, positively charged particles show the lowest number of different proteins in vivo, and particles with a negative charge show the lowest number of different proteins in vitro. This surprising result could have a high impact on discussions 
concerning the value of in vitro experiments related to toxicity or uptake mechanism. Both these mechanisms depend strongly on the composition of the protein corona.

Evaluation of soft corona would be an interesting further step to understand the detail of protein adsorption and its relations to biological processes. This will be useful not only for diagnostic and drug delivery applications, but also for assessing nanosafety of NPs for future applications.

\section{Competing interests}

The authors declare that they have no competing interests.

\section{Acknowledgements}

We would like to acknowledge the Nanodiara FP7 Project of the EU Framework 7 Programme, Contract No. NMP4-LA2009-228929, and the Swiss National Science Foundation (SNSF), Fund No. 205321-120161/1, for their financial support.

\section{Notes and references}

${ }^{a}$ Laboratory of Powder Technology, Ecole Polytechnique Fédérale de Lausanne, CH-1015 Lausanne, Switzerland.

${ }^{b}$ Department of Nanotechnology and Nanotechnology Research Center, Faculty of Pharmacy, Tehran University of Medical Sciences, Tehran, Iran.

${ }^{c}$ Division of Pediatric Cardiology, Department of Pediatrics, Stanford University School of Medicine, Stanford, California 94305-5101, United States.

${ }^{d}$ Department of Experimental Vascular Medicine, Academic Medical Center, Amsterdam, the Netherlands.

$e$ Department of Cell Biology, University Medical Center Groningen, University of Groningen, Groningen, the Netherlands.

$f$ Department of Gastroenterology and Hepatology, Erasmus Medical Center, Rotterdam, the Netherlands.

${ }^{g}$ Department of Radiology, University of Geneva and Geneva University Hospital 1211 Geneva 14, Switzerland.

$\dagger \quad$ Electronic Supplementary Information (ESI) available: Summary table of identified proteins. See DOI: 10.1039/b000000x/

*Corresponding Authors: (MM) email: mahmoudi-m@tums.ac.ir; (FR) email: f.rezaee@umcg.nl; (HH) email: heinrich.hofmann@epfl.ch

1. D. Ghosh, Y. Lee, S. Thomas, A. G. Kohli, D. S. Yun, A. M. Belcher and K. A. Kelly, Nature nanotechnology, 2012, 7, 677-682.

2. M. E. Lobatto, V. Fuster, Z. A. Fayad and W. J. M. Mulder, Nature Reviews Drug Discovery, 2011, 10, 835-852.

3. S. K. Mouli, L. C. Zhao, R. A. Omary and C. S. Thaxton, Nature Reviews Urology, 2010, 7, 84-93.

4. A. Schroeder, D. A. Heller, M. M. Winslow, J. E. Dahlman, G. W. Pratt, R. Langer, T. Jacks and D. G. Anderson, Nature Reviews Cancer, 2012, 12, 39-50.

5. S. Tong, S. Hou, Z. Zheng, J. Zhou and G. Bao, Nano letters, 2010, 10, 4607-4613.

6. H. Wei, N. Insin, J. Lee, H. S. Han, J. M. Cordero, W. Liu and M. G. Bawendi, Nano letters, 2012, 12, 22-25.
7. M. Mahmoudi, H. Hofmann, B. Rothen-Rutishauser and A. Petri-Fink, Chemical reviews, 2012, 112, 2323-2338.

8. M. A. Dobrovolskaia and S. E. McNeil, J Control Release, 2013, 172, 456-466.

9. A. E. Nel, L. Mädler, D. Velegol, T. Xia, E. M. V. Hoek, P. Somasundaran, F. Klaessig, V. Castranova and M. Thompson, Nature materials, 2009, 8, 543-557.

10. T. Cedervall, I. Lynch, S. Lindman, T. Berggård, E. Thulin, H. Nilsson, K. A. Dawson and S. Linse, Proceedings of the National Academy of Sciences, 2007, 104, 2050-2055.

11. Z. W. Lai, Y. Yan, F. Caruso and E. C. Nice, ACS nano, 2012, 6, 10438-10448.

12. M. P. Monopoli, C. Åberg, A. Salvati and K. A. Dawson, Nature nanotechnology, 2012, 7, 779-786.

13. M. P. Monopoli, D. Walczyk, A. Campbell, G. Elia, I. Lynch, F. Baldelli Bombelli and K. A. Dawson, Journal of the American Chemical Society, 2011, 133, 2525-2534.

14. D. Walczyk, F. B. Bombelli, M. P. Monopoli, I. Lynch and K. A. Dawson, Journal of the American Chemical Society, 2010, 132, 5761-5768.

15. M. J. Hajipour, S. Laurent, A. Aghaie, F. Rezaee and M. Mahmoudi, Biomaterials Science, 2014, DOI: 10.1039/c4bm00131a.

16. M. Rabe, D. Verdes and S. Seeger, Advances in colloid and interface science, 2011, 162, 87-106.

17. C. Rocker, M. Pozl, F. Zhang, W. J. Parak and G. U. Nienhaus, Nature Nanotechnology, 2009, 4, 577-580.

18. U. Sakulkhu, M. Mahmoudi, L. Maurizi, J. Salaklang and H. Hofmann, Scientific reports, 2014, 4, 5020.

19. A. Chastellain, A. Petri and H. Hofmann, J Colloid Interf Sci, 2004, 278, 353-360.

20. A. Petri-Fink, M. Chastellain, L. Juillerat-Jeanneret, A. Ferrari and H. Hofmann, Biomaterials, 2005, 26, 2685-2694.

21. R. M. Cornell and U. Schwertmann, The Iron Oxides: Structure, Properties, Reactions, Occurences and Uses., WILEY-VCH Verlag GmbH \& Co. KGaA,Weinheim, 2 edn., 2006.

22. H. B. Lee and M. D. Blaufox, Journal of nuclear medicine : official publication, Society of Nuclear Medicine, 1985, 26, 72-76.

23. L. Maurizi, U. Sakulkhu, A. Gramoun, J. P. Vallee and H. Hofmann, The Analyst, 2014, 139, 1184-1191.

24. M. Mahmoudi, S. Laurent, M. A. Shokrgozar and M. Hosseinkhani, ACS Nano, 2011, 5, 7263-7276.

25. M. Dashty, V. Akbarkhanzadeh, C. J. Zeebregts, C. A. Spek, E. J. Sijbrands, M. P. Peppelenbosch and F. Rezaee, Scientific reports, 2012, 2, 787.

26. Y. J. Jiang, A. Schadlich, E. Amado, C. Weis, E. Odermatt, K. Mader and J. Kressler, J Biomed Mater Res B, 2010, 93B, 275-284.

27. M. Chanana, P. Rivera Gil, M. A. Correa-Duarte, L. M. LizMarzan and W. J. Parak, Angewandte Chemie, 2013, 52, 4179-4183.

28. P. d. Pino, B. Pelaz, Q. Zhang, P. Maffre, G. U. Nienhaus and W. J. Parak, Materials Horizons, 2014, 1, 301.

29. L. Maurizi, U. Sakulkhu, L. A. Crowe, V. M. Dao, N. Leclaire, J.-P. Vallée and H. Hofmann, RSC Advances, 2014, 4, 11142 .

30. K. B. Saebo, Disseration at the University of Uppsala 2004., 2004.

31. K. Furumoto, K.-i. Ogawara, S. Nagayama, Y. Takakura, M. Hashida, K. Higaki and T. Kimura, J. Controlled Release, 2002, 83, 89-96. 
32. A. von Eckardstein, J. R. Nofer and G. Assmann, Arteriosclerosis, thrombosis, and vascular biology, 2001, 21, 13-27.

33. M. Dashty, M. M. Motazacker, J. Levels, M. de Vries, M. Mahmoudi, M. P. Peppelenbosch and F. Rezaee, Thrombosis and haemostasis, 2014, 111, 518-530. 